\title{
Examination of burnout levels and academic procrastination of university students
}

\author{
Gönül Tekkurşun Demir ${ }^{1}$, Alperen Halıcı ${ }^{1 \mathrm{a}}$, and Can Çavin Ötkan ${ }^{2}$ \\ ${ }^{1}$ Faculty of Sport Science, Gazi University, 06000 Ankara, Turkey \\ ${ }^{2}$ Faculty of Sport Science, Gazi University/YüzüncüY1l University, 06000 Ankara, Turkey
}

\begin{abstract}
In this study, the relationship between the academic procrastination and the students' burnout levels was examined. 406 students from different departments at Gazi University Sports Sciences Faculty participated in the research. In order to collect data, the student version of Maslach's Burnout Inventory and the Academic Procrastination Scale (APS) were used in the study. It was determined that the students at the faculty of sports science did not show any significant difference in terms of gender variable according to MBI-SF and APS. When analyzed in terms of department variable, there was a significant difference in the MBI-SF subscales, while no significance was observed in the total score of APS. Similar results were obtained in the APS total scores among the grades; but there was significance in the subscales of MBI-SF. The analyses indicated that a statistically significant negative relationship at medium level was found between the MBI-SF and APS. The results of the analyses also indicated that there was a statistically significant negative relationship between academic procrastination and student burnout levels. Keywords: burnout, academic procrastination, sports, students' burnout syndrome
\end{abstract}

\section{Introduction}

University life is important both for academic and social development of students. During their university education, students can gain new experiences and opportunities for development, change, maturation and growth while at the same time they can experience some personal and academic problems. In this context, difficulties experienced during university education can affect the functions and performances of the students at different levels [13]. Given the limited ability of students to overcome the difficulties experienced, particularly their academic life can be negatively affected by these difficulties. For this reason, it can be stated that university students have to overcome many personal and environmental difficulties during their academic life [5]. One of the problems that

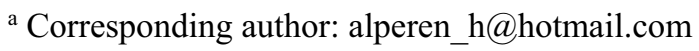


university students have to overcome during their university education is the academic procrastination. Academic procrastination is a problem seen in the fields expected from students at universities such as preparing for the exams, doing homework, meeting with the academic advisor and completing the projects $[14,19]$. Another problem that university students have to overcome is the feeling of burnout. Burnout is defined as a physical, emotional, and mental fatigue syndrome which is caused by a long-term relationship in which feelings are intensely experienced [31]. Maslach and Jackson [24] defined burnout as a syndrome with physical and mental dimensions involving physical exhaustion, long-term fatigue, desperation and despair, along with negative attitudes of the individual towards his/her work, life and other people. Studies in the literature indicate that the feeling of burnout is a common problem among students; but it is also clear that the studies about student burnout are not common in our country [22, 26, 35, 36]. It is known that academic procrastination frequently seen in university students increases the level of chronic stress experienced by students. In this context, it can be expected that levels of burnout resulting from stress in students may also have an impact on their academic procrastination. This study aims to examine the burnout levels resulting from stress of university students in sports sciences and the academic procrastination problem which is common in students in terms of various demographic variables.

\section{Method}

\subsection{Research model}

Quantitative research model was used in the study. Quantitative research is a type of research that can set forth phenomena and events in a way that they can be observed, measured, and numerically expressed by objectifying them [9]. The purpose of quantitative research is to objectively measure the social behaviors of individuals through similar means such as tests and questionnaires and to explain them numerically. This research is a relational study in the scan pattern which is a descriptive research method.

\subsection{Universe and sampling}

Students enrolled at the Faculty of Sports Sciences at Gazi University in Ankara in the second semester of the academic year 2016-2017 constitute the universe of this research. It was determined the total number of the students at the departments of coaching education $(n=507)$, recreation $(n=271)$, sports management $(n=231)$ and physical education and sports teaching $(n=291)$ at Gazi University was 1300 . The sample group of the study consisted of a total of 406 students, 150 female and 256 male students, who attended their classes regularly. 128 students of this group were enrolled at the department of coaching education; 92 were enrolled at the department of recreation; 91 were enrolled at the department of sports management and 95 were enrolled at the department of physical education and sports teaching. The research also includes information on the grade level and gender of the students at the faculty of sports science participating in the study.

\subsection{Data collection tools}

In the research, "Personal Information Form" was used by the researchers to determine the demographic characteristics of the participants. "Maslach Burnout Inventory-Student Form (MBI-SF)", composed of 13 items, developed by Schaufeli et al. [33] and translated into Turkish by Çapri, Gündüz and Gökçakan [10] was used to determine the burnout levels of students. The "Academic Procrastination Scale (APS)" developed by Çakıcı [11] was used 
as the data collection tool in order to determine the academic procrastination levels of the students.

\subsection{Analysis of data}

Data collected from the participants in the research was subjected to statistical analysis in the SPSS 23 package program. Before deciding on the statistical methods to be applied, the values of Skewness and Kurtosis (normal distribution of the data) and Levene (equality of variance) tests were performed. In this context, it was determined that the Skewness and Kurtosis values of each independent variable ranged between +-1. According to this; if the skewness coefficient is within the limits of +-1 , it is interpreted that the scores do not show a significant deviation from the normal distribution [8]. After testing the homogeneity of the variances of the variables with normal distribution, these variables were analyzed by parametric test methods. Frequency, arithmetic mean, standard deviation were used in the analysis of data; and t-test, one-way analysis of variance (ANOVA), and Post-Hoc test statistics (Tukey HSD) tests were used for independent samples.

\section{Findings}

This section includes the findings and interpretations obtained as a result of subjecting the analyses obtained from the participants to various statistical processes.

Table 1. Independent group $t$ test results to determine whether or not there is differentiation according to gender variable

\begin{tabular}{|c|c|c|c|c|c|c|c|}
\hline Variable & Gender & $\mathbf{N}$ & $\overline{\mathbf{x}}$ & Ss & df & $\mathrm{t}$ & p \\
\hline \multirow{2}{*}{ Burnout } & Female & 256 & 15,5664 & 5,29108 & \multirow{2}{*}{404} & \multirow{2}{*}{$-1,444$} & \multirow{2}{*}{, 150} \\
\hline & Male & 150 & 16,3267 & 4,81677 & & & \\
\hline \multirow{2}{*}{ Depersonalization } & Female & 256 & 11,5156 & 4,53913 & \multirow{2}{*}{404} & \multirow{2}{*}{,- 920} & \multirow{2}{*}{, 358} \\
\hline & Male & 150 & 11,9267 & 3,99176 & & & \\
\hline \multirow{2}{*}{ Competence } & Female & 256 & 14,1836 & 3,38646 & \multirow{2}{*}{404} & \multirow[t]{2}{*}{,- 106} & \multirow{2}{*}{,915 } \\
\hline & Male & 150 & 14,2200 & 3,21880 & & & \\
\hline \multirow{2}{*}{$\begin{array}{c}\text { Academic } \\
\text { Procrastination }\end{array}$} & Female & 256 & 57,8711 & 13,12664 & \multirow{2}{*}{404} & \multirow{2}{*}{$-1,424$} & \multirow{2}{*}{, 155} \\
\hline & Male & 150 & 59,7133 & 11,59804 & & & \\
\hline
\end{tabular}

$* \mathrm{p}<05$

In Table 1, whether or not the participants' burnout levels in terms of gender variable and academic procrastination showed significant differences was examined by independent samples t-test. Accordingly, the participants' burnout levels and academic procrastination do not show any significant difference in terms of gender $(\mathrm{p}>, 05)$.

Table 2. Anova results in terms of department variable

\begin{tabular}{|c|c|c|c|c|c|c|c|c|c|}
\hline \multicolumn{2}{|c|}{ Department } & $\mathbf{N}$ & $\overline{\mathbf{x}}$ & $\begin{array}{l}\text { Variance } \\
\text { Source }\end{array}$ & $\begin{array}{l}\text { Sum of } \\
\text { squares }\end{array}$ & $\begin{array}{c}\text { Average of } \\
\text { Squares }\end{array}$ & $\mathbf{F}$ & $\mathbf{p}$ & $\begin{array}{l}\text { Significant } \\
\text { Difference }\end{array}$ \\
\hline \multirow{4}{*}{ 䓂 } & $\mathrm{CE}$ & 128 & 15,94 & Inter & & & \multirow{4}{*}{$7,19^{*}$} & \multirow{4}{*}{, 000} & \multirow{4}{*}{$\begin{array}{c}\text { PEST }>\text { CE-R- } \\
\text { SM }\end{array}$} \\
\hline & $\mathrm{R}$ & 92 & 14,84 & Groups & 542,437 & & & & \\
\hline & SM & 91 & 14,74 & \multirow{2}{*}{ In-Group } & \multirow[t]{2}{*}{10108,095} & \multirow{2}{*}{$\begin{array}{l}180,81 \\
25,145\end{array}$} & & & \\
\hline & PEST & 95 & 17,73 & & & & & & \\
\hline \multirow{4}{*}{ 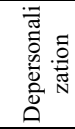 } & $\mathrm{CE}$ & 128 & 11,39 & Inter & \multirow{4}{*}{$\begin{array}{c}632,105 \\
7012,006\end{array}$} & \multirow{4}{*}{$\begin{array}{l}210,70 \\
17,443\end{array}$} & \multirow{4}{*}{$12,08 *$} & \multirow{4}{*}{, 000} & \multirow{4}{*}{$\begin{array}{c}\text { PEST }>\text { CE-R- } \\
\text { SM }\end{array}$} \\
\hline & $\mathrm{R}$ & 92 & 10,77 & Groups & & & & & \\
\hline & SM & 91 & 10,67 & \multirow{2}{*}{ In-Group } & & & & & \\
\hline & PEST & 95 & 13,86 & & & & & & \\
\hline \multirow{4}{*}{ 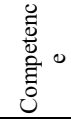 } & $\mathrm{CE}$ & 128 & 14,21 & Inter & \multirow{4}{*}{$\begin{array}{c}4,604 \\
4463,632\end{array}$} & \multirow{4}{*}{$\begin{array}{c}1,535 \\
11,104\end{array}$} & \multirow{4}{*}{,138 } & \multirow{4}{*}{,937 } & \multirow{4}{*}{ - } \\
\hline & $\mathrm{R}$ & 92 & 14,08 & Groups & & & & & \\
\hline & SM & 91 & 14,37 & \multirow{2}{*}{ In-Group } & & & & & \\
\hline & PEST & 95 & 14,11 & & & & & & \\
\hline \multirow{4}{*}{ 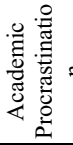 } & $\mathrm{CE}$ & 128 & 60,61 & & \multirow{4}{*}{$\begin{array}{l}1080,936 \\
63221,47\end{array}$} & \multirow{4}{*}{$\begin{array}{l}360,31 \\
157,26\end{array}$} & \multirow{4}{*}{2,291} & \multirow{4}{*}{, 078} & \multirow{4}{*}{ - } \\
\hline & $\mathrm{R}$ & 92 & 57,67 & & & & & & \\
\hline & SM & 91 & 58,82 & & & & & & \\
\hline & PEST & & & & & & & & \\
\hline
\end{tabular}


According to Table 2, as a result of the analyzes performed and as a result of the oneway analysis of variance applied for MBI-SF and APS scores according to the participants' departments, a significant difference was observed in the burnout $(F=7,19 ; p=, 000)$ and the depersonalization $(\mathrm{F}=1,8 ; \mathrm{p}=, 000)$ subscales of the burnout subscale scores. Post-Hoc test statistics (Tukey HSD) were used to determine the source of the significant difference appearing among the groups in the result of the analysis. Groups whom the score difference is in favor of are shown with $\left(^{*}\right)$. Accordingly, the averages of burnout and depersonalization scores of PEST students were found to be significantly higher than CE, R and SM students. The scores in the competency sub-dimension are similar and do not show any significant difference. It was also found that the scores for academic procrastination are higher and similar in CE students than SM, R and PEST students.

Table 3. Anova results in terms of grade variable

\begin{tabular}{|c|c|c|c|c|c|c|c|c|c|}
\hline & $\begin{array}{c}\text { Departmen } \\
\mathrm{t}\end{array}$ & $\mathrm{N}$ & $\overline{\mathrm{x}}$ & $\begin{array}{l}\text { Varianc } \\
\text { e Source }\end{array}$ & $\begin{array}{l}\text { Sum of } \\
\text { squares }\end{array}$ & $\begin{array}{c}\text { Averag } \\
\text { e of } \\
\text { Squares }\end{array}$ & $\mathrm{F}$ & $\mathrm{p}$ & $\begin{array}{c}\text { Significan } \\
\mathrm{t} \\
\text { Differenc } \\
\mathrm{e}\end{array}$ \\
\hline \multirow{4}{*}{ 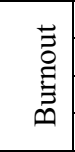 } & 1st grade & 100 & 14,1500 & \multirow{4}{*}{$\begin{array}{c}\text { Inter } \\
\text { Groups } \\
\text { In- } \\
\text { Group }\end{array}$} & 648,908 & \multirow[b]{2}{*}{216,303} & \multirow{4}{*}{$\begin{array}{c}8,6 \\
9\end{array}$} & \multirow{4}{*}{$\begin{array}{c}, 000 \\
*\end{array}$} & \multirow{4}{*}{$4>3-2-1$} \\
\hline & 2nd grade & 112 & 15,1786 & & & & & & \\
\hline & 3rd grade & 106 & 17,0094 & & 10001,6 & 24880 & & & \\
\hline & 4th grade & 88 & 17,2273 & & 2 & 24,880 & & & \\
\hline \multirow{4}{*}{ 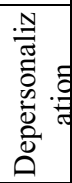 } & 1st grade & 100 & 9,8100 & \multirow{4}{*}{$\begin{array}{c}\text { Inter } \\
\text { Groups } \\
\text { In- } \\
\text { Group }\end{array}$} & & & \multirow{4}{*}{$\begin{array}{c}13 \\
4\end{array}$} & \multirow{4}{*}{$\begin{array}{l}, 000 \\
*\end{array}$} & \multirow{4}{*}{$4>3-2-1$} \\
\hline & 2nd grade & 112 & 11,1429 & & 699,575 & 233,192 & & & \\
\hline & 3rd grade & 106 & 12,6698 & & 6944,53 & & & & \\
\hline & 4 th grade & 88 & 13,2386 & & 6 & 17,275 & & & \\
\hline \multirow{4}{*}{$\begin{array}{l}0 \\
0 \\
0 \\
0 \\
\text { : } \\
0 \\
0\end{array}$} & 1st grade & 100 & 14,9800 & \multirow{4}{*}{$\begin{array}{c}\text { Inter } \\
\text { Groups } \\
\text { In- } \\
\text { Group }\end{array}$} & 159,014 & 53005 & \multirow{4}{*}{$\begin{array}{c}4,9 \\
4\end{array}$} & \multirow{4}{*}{$\begin{array}{c}, 002 \\
*\end{array}$} & \multirow{4}{*}{$1>4-2-3$} \\
\hline & 2nd grade & 112 & 13,9196 & & & & & & \\
\hline & 3rd grade & 106 & 13,3774 & & 4309,22 & 10.719 & & & \\
\hline & 4th grade & 88 & 14,6477 & & 2 & 10,119 & & & \\
\hline \multirow{4}{*}{ 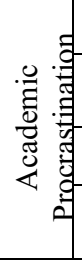 } & 1st grade & 100 & 61,0500 & \multirow{4}{*}{$\begin{array}{c}\text { Inter } \\
\text { Groups } \\
\text { In- } \\
\text { Group }\end{array}$} & & & \multirow{4}{*}{$\begin{array}{c}3,4 \\
3\end{array}$} & \multirow{4}{*}{,017 } & \multirow{4}{*}{ - } \\
\hline & $2^{\text {nd }}$ grade & $\begin{array}{c}11 \\
2 \\
\end{array}$ & $\begin{array}{c}59,776 \\
8 \\
\end{array}$ & & $\begin{array}{c}1000,50 \\
2\end{array}$ & 535,501 & & & \\
\hline & $3^{\text {rd }}$ grade & 106 & 56,1321 & & 62695,9 & 155,960 & & & \\
\hline & $4^{\text {th }}$ grade & 88 & $\begin{array}{c}57,068 \\
2\end{array}$ & & 1 & & & & \\
\hline
\end{tabular}

As shown in Table 3, as a result of the one-way analysis of variance applied for MBI-SF and APS scores according to participants' grades, there was a significant difference in the burnout $(\mathrm{F}=8,69 ; \mathrm{p}=, 000)$, depersonalization $(\mathrm{F}=13,4 ; \mathrm{p}=, 000)$ and competence $(\mathrm{F}=4,94$; $\mathrm{p}=, 000$ ) subscales of MBI-SF. Post-Hoc test statistics (Tukey HSD) were used to determine the source of the significant difference appearing among the groups in the result of the analysis. Groups whom the score difference is in favor of are shown with $(*)$. It was determined that the scores of the $4^{\text {th }}$ graders in the burnout and depersonalization subdimensions showed higher and significant difference than those of $3^{\text {rd }}, 2^{\text {nd }}$ and $1^{\text {st }}$ graders. It was also determined that the scores of 1 st graders in the competence sub-dimension were higher at a significant level than those of $4^{\text {th }}, 2^{\text {nd }}$ and $3^{\text {rd }}$ graders. Finally, it was seen that there was not a significant difference in the participants' academic tendencies and that they had similar scores in this regard. 
Table 4. Burnout and academic procrastination correlation results

\begin{tabular}{ccccc}
\hline Variable & Burnout & Depersonalization & Competence & Total Burnout \\
\hline Academic &,$- 466^{* *}$ &,$- 462^{* *}$ &, $265^{* *}$ &,$- 401^{* *}$ \\
$\begin{array}{c}\text { Procrastination } \\
\text { Total Score }\end{array}$ & & & & \\
\hline
\end{tabular}

${ }^{*} \mathrm{p}<.05 ;{ }^{* *} \mathrm{p}<.01$

In Table 4, a Pearson Moment Correlation analysis was performed to determine the relationship between MBI-SF and APS. According to this result, it can be said that both scales are related to each other. The result of the analysis indicates that the total scores of MBI-SF and APS were statistically significant $(\mathrm{r}=-401, \mathrm{p}<, 001)$. There was a negative relationship at a medium level between the total score of APS and burnout and depersonalization sub-dimensions of MBI-SF while there was a positive relationship at a low level between the total score of APS and the competence sub-dimension.

\section{Discussion and conclusion}

This study aimed to determine the MBI-SF and APS of $1^{\text {st }}, 2^{\text {nd }}, 3^{\text {rd }}$ and $4^{\text {th }}$ graders at the departments of recreation, coaching education, sports management, physical education and sports teaching at the faculty of sports sciences at Gazi University in 2017. Before starting the analysis of the study, the values of Kurtosis and Skewness (normal distribution of the data) for each independent variable were examined and the result was that the data showed a normal distribution. No significant difference was determined when the scores from MBISF were evaluated in terms of gender. In the light of these findings, we can say that male and female participants have a similar burnout level and academic procrastination. This may be interpreted by the fact that female and male participants join in and be tired of everyday life to the same degree. In parallel with the present research, Adoum [2], Kutsal [22], Esteve [15], LaForge [23], Alexander and Onwuegbuzie [23], Onwuegbuzie [25], Kachgal, Hansen and Nuther [20], Watson [39], Hess, Sherman, and Goodman [17] did not also find a significant difference in burnout levels in terms of gender. Unlike the present research, while Y1lmaz [42], Gündüz et al., [16] suggested that women showed the feeling of burnout more than men, Tansel [36], on the other hand, stated that male students experienced the feeling of burnout more than female students. According to the result of the analysis, when the scores from APS were evaluated in terms of gender, no significant difference was found between male and female participants. According to these results, in parallel with the research, there are also results that found no significance in terms of gender $[3,17,20,23,25]$. Some different results were also found in the literature. The first of these results indicates that female students showed less academic procrastination than male students $[4,28,29,34,38]$; while some other studies, on the contrary, pointed out that male students showed less academic procrastination than female students [30, 40]. According to the analyzes made, when MBI-SF scores were evaluated in terms of the participants' departments, there was a significant difference in the sub-dimensions of burnout and depersonalization while there was not a significant difference in the subdimension of competence and the total score of APS. In parallel with the results of this research, there are also studies $[16,36]$ which determined significant difference in terms of departments. When total scores from APS were evaluated in terms of the department variable, no significant difference was found. Accordingly, it can be said that the majority of participants have similar procrastination behavior. When scores from MBI-SF are evaluated in terms of grades, it was determined that there are significant differences in terms of burnout, depersonalization and competence sub-dimensions. It was also found out 
that the students at higher grades showed the feeling of burnout more than the other students. It is seen that as the grade level increased, so did the level of burnout. In parallel with this result, there are also other similar results in the literature $[1,12,21,27]$. The higher the grade level at schools in our country, the more difficult and important the lessons get. When the total scores from APS were evaluated in terms of the grade variable, no significant difference was found. Accordingly, it can be said that the majority of the participants have similar procrastination behaviors. There are studies $[6,7,32,37]$ which suggest that as the grade level gets higher, so does the academic procrastination. In the light of the analyses, it was determined in the research that there is a significant relationship between the burnout levels and academic procrastination of the participants. Parallel to this research, Balkıs [5] also obtained similar results. It was determined that students who show academic procrastination do not do their homework on time, do not study for their examinations on time, and start studying for their exams just before the exam [18]. It can also be said that students who tend to show academic procrastination put a lot of effort into studying for their exams in a short time, which, in turn, affects their burnout levels. Accordingly, the level of burnout also increases in parallel with the increase in academic procrastination [41].

This research argues that students' burnout levels and academic procrastination are interrelated. The reason for the academic procrastination of university students can be shown as an increase in their burnout levels.

\section{References}

1. Addis, R.S. Burnout among undergraduate athletic training students, Dissertation. California University, U.S.A. (2006).

2. Adoum, Y., S. Determination of Burnout Levels of Turkish and Foreign Students Studying at Süleyman Demirel University, Süleyman Demirel University, Institute of Social Sciences, Department of Business Administration, Master's Thesis, Isparta. (2017).

3. Alexander, S. E. ve Onwuegbuzie, J. A. Academic procrastination and the role of hope as a coping strategy. Personality and Individual Differences, 42, 1301-1310. (2007).

4. Balkıs, M., Buluş, M., Duru, E. and Duru, S. Examination of academic procrastination of University Students in terms of various variables. Ege Journal of Education, 7, 57-73. (2006).

5. Balkıs, M. The relationship between the pre-service teachers' tendency to delay and their ways of thinking and decision making. Unpublished Doctorate Thesis, Dokuz Eylül University Institute of Educational Sciences. İzmir. (2006).

6. Balkıs, M. The Relationship between the pre-service teachers' tendency to delay and their ways of decision making. Pamukkale University Faculty of Education Journal, 1(21), 67-83. (2007).

7. Berber Çelik, Ç. and Odac1, H. Explanation of Academic Procrastination Behavior In Terms of Some Personal and Psychological Variables, H. U. Journal of Education 30(3): 31-47. (2015).

8. Büyüköztürk, Ş. Data Analysis Handbook for Social Sciences. (Edition 16). Ankara: Pegem Akademi. (2012).

9. Creswell, J. W. Research design: Qualitative, quantitative, and mixed methods approaches (2nd ed.). Thousand Oaks: Sage Publications. (2003).

10. Çapri, B., Gündüz, B. and Gökçakan, Z. Adaptation of Maslach Burnout InventoryStudent Form (MBI-SF) into Turkish: Validity and Reliability Study, Cukurova University Faculty of Education Journal. 40 (1), 134-147. (2011). 
11. Çakıcı, D.Ç. Examination of General and Academic Procrastination Behavior in High School and University Students. Unpublished Master's Thesis, Ankara University Faculty of Education Sciences, Institute of Educational Sciences, Ankara. (2003).

12. Çapulcuoğlu, U. and Gündüz, B. Examination of burnout in high school students in terms of the variables of gender, grade level, school type and perceived academic achievement. Trakya University Faculty of Education Journal, 3(1). (2013).

13. Duru, E. "The direct and indirect roles of social support and social commitment in the process of interpreting loneliness in university integration process", Journal of Turkish Psychological Counselling and Guidance, 29, 13-22. (2008).

14. Dryden, W. Overcoming Procrastination (Translated by Günhan Günay) Istanbul: Erdemir Publishing House. (2000).

15. Esteve, E. B., Well Being and Performance in Academics Settings: The Predicting Roles of Self Efficacy, Doktora Tezi, University Jaume I de Castello. (2008).

16. Gündüz, B., Çapri, B., and Gökçakan, Z. Examination of Burnout Levels of University Students, Dicle University, Ziya Gökalp Faculty of Education Journal, 19 (2012), 3855. (2012).

17. Hess, B., Sherman, M. F., Goodman, M. Eveningness predicts academic procrastination: The mediating role of neuroticism. Journal of Social Behavior ve Personality, 15 (5), 61- 75. (2000).

18. Jackson, T., Weiss, E.K., Lundquist, J.L.,\& Hooper, D. The Impact of Hope, Procrastination and Social Activity on Academic Performance of Midwestern College Students. Education, 124,(2), pp. 310-320. (2001).

19. Johnson, J. L., \& Bloom, A. M. An Analysis Of The Contribution Of The Five Factors Of Personality To Variance In Academic Procrastination. Personality Ve Individual Differences, 18, 127-133. (1995).

20. Kachgal, M. M., Hansen, L. S., ve Nutter, K. J. Academic procrastination prevention/intervention: Strategies and recommendations. Journal of Developmental Education, 25, 14-21. (2001).

21. Kutsal D. and Bilge F. Burnout and social support levels of high school students. Education and Science, 37(164), 283-297. (2012).

22. Kutsal, D., Examination of Burnout of High School Students, Unpublished Master's Thesis, Hacettepe University, Institute of Social Sciences, Ankara. (2009).

23. LaForge, M. C. Applying explanatory style to academic procrastination. Clemson University, South Carolina, USA. (2005).

24. Maslach, C., ve Jackson, S. E. The measurement of experienced burnout, Journal of Occupational Behavior, 2, 99-113. (1981).

25. Onwuegbuzie, A. J. Academic procrastination and statistics anxiety. Assessment ve Evaluation in Higher Education, 29 (1), 3-19. (2004).

26. Ören, N. and Türkoğlu, H. Burnout in Pre-service Teachers, Muğla University Institute of Social Sciences Journal, 16, 30-42. (2006).

27. Öztan, S. Examination of school burnout of secondary school 6th, 7th and 8th graders in terms of their life satisfaction and self-construal perception, Master's Thesis, Istanbul Arel University Institute of Social Sciences, İstanbul. (2014).

28. Özer, A. and Altun, E. Reasons for Academic Procrastination of University Students. Mehmet Akif Ersoy University, Faculty of Education Journal, 21, 45-72. (2011).

29. Prohaska, V., Morrill, P., Atiles, I., ve Perez, A. Academic procrastination by nontraditional students. Journal of Social Behavior and Personality, 15 (5), 125- 135. (2000).

30. Paludi, M.A., ve Frankell-Hauser, J. An idiographic approach to the study of women's achivement striving. Psychology of Women Quarterly, 10, 89-100. (1986). 
31. Pines, A. M. The Burnout Measure Short Version (BMS), International Journal of Stress Management, 12(1), 78-88. (2005).

32. Rosario, P., Costa, M., Nunez, J.C., \& Gonzales-Pienda, J. Academic procrastination: Associations with personal, school, and family variables. The Spanish Journal of Psychology, 12(1), 118-127. (2009).

33. Schaufeli, W. B., Salanova, M., Gonzalez-Roma, V., ve Bakker, A. The measurement of burnout and engagement: A confirmatory factor analytic approach. Journal of Happiness Studies, 3, 71-92. (2002).

34. Senecal, C., Julien, E., ve Guay, F., Role conflict and academic procrastination: A selfdetermination perspective. European Journal of Social Psychology, 33,135-145. (2003).

35. Tümkaya, S., Çam, S., \& Çavuşoğlu, İ. Adaptation into Turkish, Validity and Reliability Studies of Short Version of Burnout Scale, Çukurova University Institute of Social Sciences Journal, 18 (1), 387-398. (2009).

36. Tansel, B., Examination of Burnout Levels of University Students, Çukurova University Faculty of Education Journal, 44(2), 241-268. (2015).

37. Yeşil, R. \& Şahan, E. Reasons why pre-service teachers delay their academic affairs. Abant İzzet Baysal University Faculty of Education Journal, 12(2), 219-236. (2012).

38. Van Eerde, W. Procrastination at work and time management training. Journal of Psychology, 137, 421- 435. (2003).

39. Watson, D. C. Procrastination and the five-factor model: A facet level analysis. Personality and Individual Differences, 30, 149-158. (2001).

40. Washington, J. A. The relationship between procrastination and depression among graduate and professional students across academic programs: Implications for counseling. Unpublished Doctoral Dissertation. Texas Southern University, Texas, USA. (2004).

41. Van Wyk, L. The relationship between procrastination and stress in the life of the high school teacher. Unpublished Master thesis. University of Pretoria. (2004).

42. Yilmaz, T.D. Levels of Burnout of the Students of Specialty in Medicine at the Hospitals of the Faculty of Medicine, Ankara University and Related Factors, Unpublished Master's Thesis, Ankara University, Ankara. (2009). 